\title{
Agnieszka Stolarska*
}

\section{ROLA KIEROWNIKA W ZARZĄDZANIU ZESPOŁEM PROJEKTOWYM}

Z a r y s t r e ś c i: Artykuł dotyka kwestii ról kierowniczych. Jego celem jest przedstawienie roli kierownika w organizacji oraz roli zarządzającego projektem. Autor przedstawia istotę menedżera, a także jego role w przedsiębiorstwie. Ponadto, przybliża on idee projektu, zespołu projektowego oraz jego kierownika. Autor pokazuje podobieństwo między rolą zarządzających organizacjami i zespołami projektowymi.

S ł o w a k l u c z o w e: kierownik, rola kierownika, projekt, zespół projektowy, kierownik zespołu projektowego

\section{WSTĘP}

O rolach menedżerów powstało już wiele publikacji. We wszystkich książkach dotyczących zarządzania można znaleźć informacje na ten temat. Powstaje jednak pytanie, czy rola kierownika, jaką pełni on w organizacji jest taka sama jak jego rola w zarządzaniu zespołem projektowym? Celem niniejszych rozważań jest porównanie ról zarządzających przedsiębiorstwami a ról kierowników projektów.

* Adres do korespondencji: Agnieszka Stolarska, Uniwersytet Ekonomiczny w Poznaniu, Wydział Zarządzania, Katedra Teorii Organizacji i Zarządzania, al. Niepodległości 10, 61-875 Poznań, e-mail: agnieszkastolarska@onet.eu. 


\section{POJĘCIE KIEROWNIKA I ROLE JAKIE PEŁNI}

Kierownik jest osobą, która bierze na siebie odpowiedzialność za zorientowanie organizacji na osiąganie wyznaczonych celów [Stoner, Wankel, 1994, s. 27]. Priorytetem menedżera jest realizowanie procesu, jakim jest zarządzanie, do którego zaliczane są cztery podstawowe funkcje: planowanie, organizowanie, przewodzenie a także kontrolowanie [Griffin, 2002, s. 38-39]. Ponadto zarządzający odpowiadają za zasoby organizacji, zarówno ludzkie jak i rzeczowe, informacyjne itp. [Piotrkowski, 2006, s. 48]. Co więcej, działanie kierownika organizacji jest podyktowane obowiązkiem zapewnienia współmiernej wymiany pomiędzy przedsiębiorstwem a otoczeniem, co w rezultacie przyczynia się do osiągania zamierzonych efektów ekonomicznych [Cyfert, Krzakiewicz, 2015, s. 25]. Wnioskować zatem można, iż menedżerowi, zważywszy na istotę wykonywanej przez nich pracy, są nieodzownym elementem istnienia organizacji.

Pracownicy szczebla kierowniczego odgrywają różnorakie role. Role jakie pełnią zarządzający określa się jako wewnętrznie usystematyzowane zespoły zachowania, które są utożsamiane ze stanowiskiem [Mintzberg w: Harvard Business Review, 2005, s. 20]. Mintzberg, obserwując pracę menedżerów, wyodrębnił trzy główne typy ról, jakie pełnią kierownicy: interpersonalne, informacyjne oraz decyzyjne, następnie pośród nich wyróżnił dziesięć podkategorii [Griffin, 2002, s. 52].

Pierwszą kategorią są role interpersonalne, w ramach których wyróżnia się reprezentanta, przywódcę a także łącznika [Griffin, 2002, s. 53]. Powyższy typ opisuje kreowanie zachowań wśród pracowników, w rezultacie których wykonywać będą oni powierzone zadania [Czermiński i in., 2002, s. 90]. Co więcej, obowiązki wynikające z pełnienia ról w tej kategorii są istotne dla efektywnego działania przedsiębiorstwa, mimo że nie wymagają podejmowania ważnych decyzji [Mintzberg w Harvard Business Review, 2005, s. 21]. Pierwszą podkategorią tutaj wyodrębnioną jest reprezentant, określany również w literaturze jako przywódca symboliczny. Menedżerowie podejmują tutaj czynności, które mają charakter symboliczny [Griffin, 2002, s. 52]. Misja w tym przypadku, jaka powierzana jest kierownikom, obrazuje kreowanie kontaktów organizacji z jej otoczeniem, zarówno wewnętrznym, jak również zewnętrznym a także kształtowaniu wizerunku podległego zespołu oraz przedsiębiorstwa [Koźmiński, Piotrowski, 2000, s. 69]. Rezultatem pełnienia tej roli dla firmy bądź zespołu jest fakt, iż postawy pracowników są kształtowane przez zarządzającego, co $\mathrm{w}$ efekcie powoduje ich większe oddanie się problemom przedsiębiorstwa bądź zespołu, do którego należą [Czermiński i in., 2002, s. 91]. Następną rolą, 
jaką zaobserwowano w ramach typu ról interpersonalnych, jest rola przywódcza, która w literaturze określana jest także liderską. Główną cechą menedżeraprzywódcy jest odpowiedzialność za podległy zespół [Mintzberg w: Harvard Business Review, 2005, s. 21]. Rola ta obejmuje określenie celów, motywacji pracowników, jak również zapewnienie warunków do pracy [Koźmiński, Piotrowski, 2000, s. 69]. Dodatkowo, kierownik pełniący opisywaną rolę wyjaśnia podległemu zespołowi, w sposób formalny bądź nieformalny, jak działać, by osiągnąć pożądany rezultat [Griffin, 2002, s. 53]. Ostatnią, ukazaną w ramach powyżej kategorii, rolą jest łącznik. Pracownik szczebla kierowniczego jest tu pośrednikiem pomiędzy osobami będącym zarówno wewnątrz organizacji czy zespołu, jak również tymi, którzy znajdują się na zewnątrz [Stoner, Wankel, 1994, s. 38]. Dodatkowo, kierownik troszczy się, by cele jego podwładnych oraz kontrahentów były bliskie celom organizacji [Czermiński i in., 2002, s. 91].

Role informacyjne obligują do przetwarzania informacji, co może być najbardziej istotnym punktem pracy menedżera, gdyż to właśnie informacja jest nieodzownym elementem procesu podejmowania decyzji [Stoner, Wankel, 1994, s. 38]. Scharakteryzowano tutaj obserwatora, rzecznika oraz propagatora informacji [Griffin, 2002, s. 54]. Obserwator nieprzerwanie poszukuje danych, przyglądając się otoczeniu [Mintzberg w: Harvard Business Review, 2005, s. 25]. Ponadto, działanie takie umożliwi zarządzającemu sprawne kierowanie zespołem [Czermiński i in., 2002, s. 91]. Rzecznik oficjalnie przekazuje informacje podległym osobom nienależącym do zespołu lub organizacji [Griffin, 2002, s. 54]. Poza tym, kierownik powiadamia pracowników na wyższych stanowiskach a także podległy zespół o oczekiwaniach drugiej strony [Czermiński i in., 2002, s. 91]. Dalej, występuje tu propagator informacji, przez co rozumie się dostarczanie personelowi informacji, które bez niego były by dla nich niedostępne [Stoner, Wankel, 1994, s. 38]. Te czynności menedżera przyczyniają się do kreowania świadomości współuczestnictwa w sukcesach przedsiębiorstwa wśród podległego zespołu [Czermiński i in., 2002, s. 91].

Ostatnią, przedstawioną przez Mintzberga, kategorią są role decyzyjne. Dotyczą one głównie decyzji, które kierownik musi podjąć [Griffin, 2002, s. 54]. $\mathrm{W}$ procesie podejmowania decyzji zasadniczą rolę pełni właśnie menedżer [Mintzberg w: Harvard Business Review, 2005, s. 26]. Opisywane są tu cztery podkategorie: przedsiębiorca, negocjator, przeciwdziałający zakłóceniom i rozdzielający zasoby [Griffin, 2002, s. 54]. Przedsiębiorca prowadzi działania, dzięki którym przedsiębiorstwo sprawnie wykonuje zadania [Czermiński i in., 2002, s. 89]. Menedżer w tej roli samodzielnie rozpoczyna wprowadzanie zmian w zespole [Stoner, Wankel, 1994, s. 38]. Co więcej, kierownikprzedsiębiorca dokłada wszelkich starań do ciągłego doskonalenia organizacji, 
co stwarza warunki do jej przystosowania do nieustannie zmieniających się warunków otoczenia [Mintzberg w: Harvard Business Review, 2005, s. 26]. Następnie, zarządzający-przeciwdziałający zakłóceniom reaguje na zdarzenia, na które nie ma wpływu [Stoner, Wankel, 1994, s. 38]. Rola ta spowodowana jest przez inną grupę bądź jednostkę, lecz nie przez kierownika [Griffin, 2002, s. 54]. Dalej, rozdzielający zasoby ustala podział kapitału między wykonawców zadań [Czermiński i in., 2002, s. 90]. W dodatku, zarządzający pełniący tę rolę kontrolują istotne decyzje podejmowane przez pracowników zespołu przed ich wdrożeniem [Stoner, Wankel, 1994, s. 38]. Ostatnią rolą jest negocjator, czyli kierownik prowadzący rozmowy biznesowe z innymi przedsiębiorstwami lub zespołami jako ich reprezentant [Griffin, 1998, s. 55]. Menedżerowie wiele czasu poświęcają roli negocjatora, ponieważ posiadają oni zasób informacji a także autorytet, co niezbędne jest negocjatorom [Stoner, Wankel, 1994, s. 38].

Powyższe role, które zobrazował Mintzberg, odnoszą się do wszystkich kierowników bez względu na szczebel zarządzania czy specjalność [Griffin, 2002, s. 52].

Reasumując powyższe rozważania można stwierdzić, iż w organizacjach menedżerowie pełnią różne role, które mogą być również odgrywane w zarządzaniu zespołem projektowym.

\section{ZARZĄDZANIE PROJEKTEM}

Projekt to czasowe przedsięwzięcie, którego celem działania jest przygotowanie produktu bądź usługi o unikatowym charakterze [Knosala, Łapuńka, 2015, s. 17]. Każdy projekt powinien posiadać następujące właściwości:

- Cel, czyli zdefiniowanie produktu wyjściowego, wyniku oraz rezultatu, co określane jest przez terminy, koszty a także wymogi, które odnoszą się do wykonywanych czynności [Nicholas, Steyn, 2012, s. 27].

- Niepowtarzalność, co oznacza wykreowanie produktu bądź usługi, które nie zostały wcześniej stworzone; unikatowa jest tu koncepcja a także jej realizacja [Trocki i in., 2003, s. 17].

- Złożoność, przez co rozumie się działania wielu działów organizacji [Trocki i in., 2003, s. 17]. Stwarzanie przedsięwzięcia odbywa się ponad strukturą organizacji, ponieważ grupuje się kompetencje i umiejętności pracowników, pochodzących z różnych wydziałów 
czy przedsiębiorstw [Nicholas, Steyn, 2012, s. 27].

- Określoność, czyli czytelne zobrazowanie działalności, zdefiniowane w czasie, miejscu oraz budżecie [Trocki i in., 2003, s. 18].

- Ryzyko oraz nowość, przed którymi zostaje postawione każde przedsiębiorstwa realizujące projekt, gdyż mogą one napotkać w jego realizacji wiele niewiadomych [Nicholas, Steyn, 2012, s. 27].

- Autonomia, czyli niezależność od wszystkich czynności, które wykonywane są w organizacji [Trocki i in., 2003, s. 18].

- Cykl życia projektu, na który składają się poszczególne działania projektu, które powodują, że zasoby projektu ulegają zmianie pod wpływem przechodzenia do następnego etapu [Nicholas, Steyn, 2012, s. 27].

Zarządzanie projektami jest współcześnie nabierającą na znaczeniu koncepcją w obrębie nauk o zarządzaniu, jaką jest zarządzanie. Kierowanie projektami polega na wykorzystaniu dostępnej wiedzy, metod, kompetencji i narzędzi celem zrealizowania oczekiwań i wymogów określonych przez zleceniodawcę przedsięwzięcia [Trocki i in., 2003, s. 27]. Ponadto, kierowanie projektami łączy wszystkie kwestie dotyczące wykonania projektów [Knosala, Łapuńka, 2015, s. 24]. Pojęcie to określa się także jako filozofię i technikę zarządzania, które skierowane jest na realizowanie jednego, zdefiniowanego rodzaju przedsięwzięcia, którym jest projekt [Nicholas, Steyn, 2012, s. 48]. Kierując projektem, powinno stosować się następujące zasady [Nicholas, Steyn, 2012, s. 49]:

- Jedna osoba, która jest jednocześnie kierownikiem, zajmuje się zarządzaniem zespołem projektowym oraz działa, pomijając tradycyjną kolejność przekazywania dyspozycji.

- Menedżer przedsięwzięcia integruje aktywność członków zespołu w całość, celem osiągnięcia zamierzonego rezultatu.

- Zgrupowanie osób z różnych działów bądź organizacji do pracowników projektu, co doprowadzi do wykorzystania umiejętności i kapitału, który jest niezbędny do realizacji celu.

- Kierownik projektu zajmuje się negocjacjami z menedżerami funkcjonalnymi, którzy ponoszą odpowiedzialność za realizację danego 
zadania i pracowników.

- Zarządzający przedsięwzięciem skupia się na zagwarantowaniu produktu wyjściowego w określonym terminie, miejscu oraz koszcie. Kierownicy funkcjonalni mają za zadanie zachować zasoby do zrealizowania celów organizacji. Powyższe obowiązki mogą spowodować spory wśród osób zajmujących się projektem.

- Dopuszczalne jest, by w projekcie istniał funkcjonalny a także projektowy sposób przekazywania poleceń, co spowoduje, że członkowie zespołu projektowego będą odpowiadać nie tylko przed zarządzającym przedsięwzięciem, lecz także przed menedżerem funkcjonalnym.

- Pomiędzy zespół projektowy i jednostki funkcjonalne, które go wspierają rozdziela się proces podejmowania decyzji, odpowiedzialność, konsekwencje oraz gratyfikacje.

- Członkowie grupy projektowej po zakończonym przedsięwzięciu powracają do swoich jednostek.

- Kierowanie projektami zapoczątkowuje pracę w funkcjach wspierających, do których może należeć dział HR, IT, księgowości itp.

Konkludując, aby sprawnie zarządzać projektem kierownicy powinni stosować powyższe działania. Przyczyni się to do osiągnięcia celu projektu, jak również do spełnienia oczekiwań klientów.

\section{ZESPÓŁ PROJEKTOWY I JEGO KIEROWNIK}

Zespół projektowy to grupa ludzi celowo dobranych do realizacji konkretnego zadania, po którym następuje jej rozwiązanie [Bielawa w: Janasz, Wiśniewska, 2014, s. 93]. Ponadto, grupę taką określa się również jako małą liczbę osób, którzy posiadają wzajemnie się uzupełniające umiejętności oraz są wspólnie odpowiedzialni na osiągnięciu wyznaczonego celu [Katzenbach, Smith, 2001, s. 26].

Kierownik projektu to osoba, która oddziałuje na podejmowane decyzje nie wydając poleceń [Nicholas, Steyn, 2012, s. 729]. Menedżer przedsięwzięcia to przełożony zdefiniowanego zespołu ludzi, których pracą zarządza a także za którą ponosi odpowiedzialność [Kisielnicki, 2014, s. 183]. Zarządzający projektem powinien posiadać następujące umiejętności [Buczkowska, 2012, 


\section{s. 22]:}

- Umiejętności porozumiewania się.

- Umiejętności organizowania, przez co rozumie się planowanie, wyznaczenie celów oraz analizę.

- Umiejętności kreowania zespołu, utożsamianie się z problemami jego uczestników a także ich motywowanie.

- Umiejętności przywódcy, czyli zachowanie będące przykładem, zdolność delegowania uprawnień i obowiązków.

- Umiejętności rozwiązywania problemów, pomysłowość, opanowanie oraz konsekwencja.

Według Nicholas'a i Steyn'a kierownicy odgrywają różnorodne role w projekcie, do których zaliczyć można [Nicholas, Steyn, 2012, s. 730]:

- Rola koordynatora- menedżerowie łączą czynności w taki sposób, aby umożliwić osiągnięcie wyznaczonych celów zachowując jednocześnie terminowość oraz trzymając się budżetu.

- Rola komunikacyjna- zarządzający otrzymuje informacje z różnych źródeł. Są to zarówno sprawozdania, podania, jak również zażalenia. Obowiązkiem kierownika jest powiadamiać członków zespołu o zasadach, celach, programach, zmianach oraz funduszach. Dzięki tej roli, menedżerowie są w hierarchii najwyżej usytuowani, co w efekcie wspomaga proces podejmowania decyzji.

- Rola motywatora- misją zarządzającego projektem jest tu wzbudzenie entuzjazmu, wpojenie uczestnikom projektu chęci dążenia do perfekcji.

- Rola inspiratora- obejmuje zaszczepienie w pracownikach zespołu wiary w osiągnięcie sukcesu, w jego wartość i realność wykonania.

- Rola przedsiębiorcy- kierownik zdobywa elementy, jakimi są fundusze, kapitał oraz ludzi, konieczne do realizacji projektu. Posiada wole walki o istnienie projektu, zważywszy na fakt, że to właśnie on ponosi odpowiedzialność za jego powodzenie bądź porażkę.

- Rola agenta zmian- zarządzający z refleksem reaguje na zdarzenia, które 
zakłócają przebieg przedsięwzięcia. Ponadto, potrafi on przezwyciężyć opór wobec zmian wśród członków podległego mu zespołu. Dodatkowo, kierownik powinien zapobiegać zmianom, które mogą doprowadzić do podwyższenia kosztów, wydłużenia czasu a także zwiększenia zakresu projektu.

Ponad wyżej wymienione role kierownicy projektów powinni być również negocjatorami, osobami rozwiązującymi konflikty oraz przywódcami [Nicholas, Steyn, 2012, s. 50].

Jak wynika z powyższych rozważań role, jakie przypisywane są kierownikom zespołów projektowych $\mathrm{w}$ dużej mierze pokrywają się $\mathrm{z}$ rolami kierowników opisywanymi przez Mintzberga.

Co ważne, kierownicy zespołów projektowych jednocześnie mogą pełnić różne role. Często o efektywności decyduje ich potencjał, cechy charakteru oraz sytuacja w jakiej się znajdują.

\section{PODSUMOWANIE}

Niniejszy artykuł stanowił próbę zobrazowania roli menedżera w zarządzaniu zespołem projektowym. Na postawie opisanych ról, jakie pełni kierownik w organizacji oraz tych, które pełni zarządzający zespołem przedsięwzięcia można stwierdzić, iż w znacznym stopniu się one pokrywają. Pomimo, że Mintzberg nie uwzględnił roli koordynatora w swoim podziale, powszechnie wiadomo, iż tak jak istnieje ona w zespole projektowym, tak można zaobserwować ją w pracy każdego kierownika. Co więcej, rola komunikacyjna, którą pełni menedżer zespołu projektowego, odzwierciedla role informacyjne. Dodatkowo, menedżer jest niekwestionowanym liderem zespołu projektowego, pełniąc również rolę motywatora oraz inspiratora, co Mintzberg określił rolą przywódcy. Ponadto, zbieżność można zaobserwować w kategorii ról decyzyjnych z rolami przedsiębiorcy i agenta zmian. Reasumując, podobieństwo między rolami, jakie pełni kierownik w organizacji a jakie w zespole projektowym, można zaobserwować niemal we wszystkich rolach, mimo tego, że w pełni pokrywają się tylko wybrane. Dysproporcje między nimi mogą wystąpić według kryterium czasowego, zważywszy na fakt, że projekt ma ściśle określony termin realizacji. Co więcej, można zauważyć, iż kierownicy w zespołach projektowych działają na różnych płaszczyznach, często projekt jest ich dodatkowym zadaniem, dlatego ważne jest łączenie zadań. Uogólniając, kierownicy zespołów projektowych a także kierownicy organizacji pod względem pełnionych przez nich ról są do 
siebie podobni.

\title{
LITERATURA
}

Bielawa A., (2014), Organizacja i funkcjonowanie zespolu projektowego [w:] Janasz K., Wiśniewska J. (red), Zarzadzanie projektami w organizacji, Diffin, Warszawa.

Buczkowska T., (2012), Zarzadzanie projektami. Project Management, Oficyna Wydawnicza Politechniki Warszawskiej, Warszawa.

Cyfert Sz., Krzakiewicz K., (2015), Podstawy zarzadzania organizacjami, Uniwersytet Ekonomiczny w Poznaniu, Poznań.

Czermiński A., Czerska M., Nogalski B., Rutka R., Apanowicz J., (2002), Zarządzanie organizacjami, Towarzystwo Naukowe Organizacji i Kierownictwa, Stoważyszenie Wyższej Użyteczności „DOM ORGANIZATORA”, Toruń.

Griffin R. W., (2002), Podstawy zarzadzania organizacjami, Wydawnictwo Naukowe PWN, Warszawa.

Katzenbach J. R., Smith D. K., (2001), Siła zespołów: wpływ pracy zespołowej na efektywność organizacji, Oficyna Ekonomiczna: Dom Wydawniczy „ABC”, Kraków.

Kisielnicki J., (2014), Zarządzanie projektami. Ludzie-procedury-wyniki, Oficyna a Wolters Kluwer business, Warszawa.

Knosala R., Łapuńka I., (2015), Operacyjne zarzadzanie projektami, Polskie Wydawnictwo Ekonomiczne, Warszawa.

Koźmiński A. K., Piotrkowski W., (2000), Zarządzanie: teoria i praktyka, Wydawnictwo Naukowe PWN, Warszawa.

Mintzberg H., (2005), Praca menedżera-fakty i mity [w:] Harvard Business Review, Przywództwo, Helion, Gliwice.

Nicholas J. M., Steyn H., (2012), Zarzadzanie projektami: zastosowania w biznesie, inżynierii i nowoczesnych technologiach, Oficyna a Wolters Kluwer business, Warszawa.

Piotrkowski K., (2006), Organizacja i zarządzanie, ALMAMER Wyższa Szkoła Ekonomiczna, Warszawa.

Stoner J. A. F., Wankel Ch., (1994), Kierowanie, Państwowe Wydawnictwo Ekonomiczne, Warszawa.

Trocki M., Grucza B., Ogonek K., (2003), Zarządzanie projektami, Polskie Wydawnictwo Ekonomiczne, Warszawa.

\section{THE ROLE OF THE DIRECTOR IN PROJECT TEAM MANAGEMENT}

\begin{abstract}
The article deals with management roles. Its main aim is to presentation of director's roles and project manager's roles in organization. The author presents the importance of the manager and his role in the company. Moreover, he/she provides the idea of the Project, Project team and the Project manager. The author presents us the similarity between the company directors' roles and Project teams.
\end{abstract}

Keywords: the manager, manager's roles, a Project, a Project team, a Project team manager 
